\title{
10 Migratory flows: a REFLECTION OF A CRISIS OF HUMAN FULFILMENT IN AFRICA?
}

\section{Jean-Baptiste Sourou ${ }^{1}$}

\section{INTRODUCTION}

The last decade has seen the Mediterranean Sea become a cemetery for black people. The International Organisation for Migration (IOM) recorded at least 20,100 deaths in 2018, and 138,000 migrants landed in Europe. The Sahara Desert has not stopped killing amongst the young people, adults and children who in one hand cross its sand dunes trying to reach the shores of the Mediterranean from where they embark to Europe or in the other are looking for seasonal employment in North Africa. ${ }^{2}$ The paths taken by African migrants towards what they believe to be the solution to their quest for a better life are numerous. There are those who reach Europe by the Atlantic Ocean from the coasts of Senegal and those Eritreans, Ethiopians and Somalis who leave the Horn of Africa, also joined by Sudanese. Nigerians, Beninese, Ghanaians, Ivorians, Gambians, Burkinabé, Malians and other West African nationalities meet in the cities of Agadez and Dirkou in Niger, where they are picked up by smugglers to cross the Sahara. When a technical breakdown or a serious accident occurs, the consequences are almost always fatal. Many of those people die.

To this must be added the deplorable actions of dishonest and unscrupulous smugglers who, failing to receive an unforeseen increase in payment of the already exorbitant transport costs of approximately 1,000 to 2,000 US dollars per passenger, abandon the migrants in the desert to die of hunger and thirst. Of course, the official number on deaths of African migrants will never tell the truth about the number of these "misadventurers" perishing in the desert and the Mediterranean, because no one knows how many they are at their departure from their country of origin. But they can least let us perceive the gravity of the African migratory phenomenon towards Europe via Italy. In 2018, Africans were at the top of the rankings of migrants who arrived in Italy, ${ }^{3}$ which is one of the principal entry points for migrants

1 Professor of Communications, Saint Augustine University of Tanzania; Founder and Director, Center of Documentation and Research on Art and Social Sciences, Republic of Benin.

2 Mounkaila H. 2015. "Africa, Europe and the Mediterranean Migration Crisis", Rutgers University, 16 October (unpublished paper). Circular migrations that also follow the existing traditional routes between sub-Saharan Africa and North Africa.

3 Melissari L. 2018 "Migranti: quanti sono stati gli sbarchi in Italia dall'inizio del 2018" [Migrants: how many have landed in Italy since the beginning of 2018], The Post Internazionale, 23 April. According to the Italian Ministry of Home Affairs, Africans at the top in 2018: Tunisia (23\%), Eritrea (15\%), Sudan (7\%), followed by Nigeria, Algeria and Côte d'Ivoire. 
in Europe, since a significant number of the rescued people, after a short time, prefer to move to Germany, France or United Kingdom amongst others. In part a tragic phenomenon, because of the number of people swallowed by the Mediterranean Sea and the Sahara sands and the horrible living conditions of migrants, the migration crisis is a complex phenomenon, because its causes are many and intertwine. This chapter aims to present some of the causes of the migration that occurs between Africa and Europe in order to demonstrate that a lack of human fulfilment in the migrant homelands is its basic reason.

\section{CAUSES OF THE PHENOMENON}

"International migration is an ancient phenomenon of human civilisation, which has shaped nations and identities around the world," says the 2017 World Food Programme (WFP) report on the roots of migration. ${ }^{4}$ In the same text, it is emphasised that mobility is an essential characteristic in the era of globalisation and that it is likely that this trend will increase because of the strong asymmetries that persist globally. Citing the work of development economist Paul Collier, ${ }^{5}$ the improved economic outlook is a major pull factor, as migration is a response to the income gap between countries. The poor tend to migrate to richer areas or those where they think they live better. "Demographic asymmetries, such as the aging and declining population in Europe and the young and expanding population in Africa, should accelerate the phenomenon," the WFP report advises, citing the work of economist Jeffrey Sachs. ${ }^{6}$ Other elements of influence to be considered include the presence and size of the diaspora population of the country of origin in the host nation. These are important factors in attracting immigrants. Malians and Senegalese, for example, tend to go to countries or places where there is already a strong community of their compatriots, because it gives them a certain moral assurance and the certainty of finding the necessary help to settle.

\section{AFRICA AND ITS MIGRANTS}

According to the World Institute for Research on Economic Aspects of Development (UNU-WIDER), the incentives that cause or contribute to migration or displacement may be structural or sporadic. ${ }^{7}$ Structural causes of displacement include negative

4 World Food Programme (WFP). 2017. “Aux racines de l'exode: sécurité alimentaire, conflits et migrations internationales" [The roots of the exodus: food security, conflicts and international migration], Rome, May.

5 WFP, "At the root of exodus", 11 (citing Collier P. 2013. Exodus: How Migration Is Changing Our World. New York: Oxford University Press).

6 According to United Nations estimates, the African population will grow from 1.216 billion to 2.5 billion in 2050 and $50 \%$ of this population will be made up of young people under 25 years of age. WFP, "At the root of exodus", 11 (citing Sachs JD. 2016. "Toward an International Migration Regime", American Economic Review 106(5):451-455).

7 Tarp F and Parviainen S. 2016. "How Should the International Community Respond to Migration and Refugees?" WIDER Angle (blog of United Nations University World 
political, economic and social developments, as well as environmental degradation, while sporadic causes include armed conflict, violence and civil unrest. Looking at Africa, it is apparent that many of the aforementioned factors in migration are especially concentrated on the continent. It can be argued that the sporadic causes are often generated by the structural ones. This is unfortunately too true in Africa, as the recent history of the continent demonstrates.

African migration across the Mediterranean has grown considerably over the last fifteen years, corresponding optimistically to the period of the "second independence of Africa". ${ }^{8}$ After the political turmoil that Africa experienced just after independence in the 1960s - political instability, successive military coups, one-party dictatorial regimes here and there - there emerged a tendency that I call the search for an African political identity after colonisation. This continued through the 1990s, when Africa was reborn through national conferences that lay the foundations for true democracy in several countries. The fall of communism and of the Berlin Wall in November 1989 were catalysts for the advent of democracy in the 1990s. These events supported and encouraged protesters across Africa who wanted radical political, economic and social change. After long years waiting for the realisation of the promises of the years of independence, Africans were disillusioned. One-party civil and military regimes had led to waste of public goods, lack of total control, opacity in the management of the economy, cult of personality, disrespect of citizens' rights, forced exile of opponents. The economic crisis of the end of 1980s, with months of unpaid wages, increased social frustration and drove everyone to exasperation, hence the birth of national conferences and the desire to create democratic states so that there could finally be real change on all fronts. ${ }^{9}$

Benin, Togo, Niger, Congo, the Democratic Republic of Congo, Gabon, Chad and Mali have tried the path of democracy by means of national conferences. The most striking case is that of Benin, which after eighteen years of military-Marxist-Leninist regime, went through a national conference towards a democratic era, with regular political elections and respect for freedom of expression, opinion and worship. If we take the case of the media, thanks to democracy and the liberalisation of the airwaves, Benin has moved from a single national radio and television channel (ORTB) and a single state newspaper (Ehuzu) to having a considerable number of information radio, newspaper and television sources. Religious communities have also multiplied alongside the Catholic, Protestant and Islamic religions that were the only ones tolerated during the revolution. Benin is also one of the few, perhaps

Institute for Development Research (UNU-WIDER), September; Parviainen S and Tarp F. 2016. "An Economist's View on Migration and Refugees", WIDER Angle; Angenendt S, Koch A and Meier A. 2016. "Development Cooperation and Addressing 'Root Causes"', Thinking Ahead: Displacement, Transition, Solutions, May.

8 Cf. Sourou JB. 2018. Rivogliono il loro pesce [They want their fish]. Allada: CEDRES, 103-115.

9 Cf. M'Bokolo E. 2002. Afrique une histoire sonore (1960-2000), RFI e INA, CD 4-Vers la démocratie: piste 2 (2'38-2'48), Paris; Ballong-Wen-Mewuda JB. 1993. "Africa", in Dizionario di missiologia [Dictionary of missiology]. Bologna: EDB, 17. 
the only, country in the world to have instituted twenty-five years ago a holiday for traditional religions, the Vodun in particular, on 10 January of every year. ${ }^{10}$

But beyond the successes or failures of these specific national experiences, a more general aspiration to democracy that has been present everywhere in Africa since the 1990s. ${ }^{11}$ Unfortunately, however, even in states where democracy seems to be established, the economic benefits do not follow or, to state it better, democracy has no concrete consequences for the development, welfare and fulfilment of citizens. During a visit made in December 2017 to Benin, a country that is quoted everywhere as an example of democracy in Africa, International Monetary Fund (IMF) director Christine Lagarde deplored the lack of progress in the social spheres of education and health, ${ }^{12}$ for example. This is also the case for Ghana, Senegal, Niger, Côte $\mathrm{d}^{\prime}$ Ivoire and Nigeria, to name a few. These are all countries where one experiences a democratic political experience - and yet many migrants come from these countries.

It is not only the lack of democracy prompts emigration to Europe, but also the presence of a form of democracy that lacks a real and concrete impact on the lives of citizens. As much as lack of democracy and its corollary in the repression of the human rights produces the waves of migrants, a striking case being Eritrea, ${ }^{13}$ so does a democracy without a minimum of economic and social well-being. For instance, the deterioration of the environment is an important cause of deprivation of well-being for every human being. But if Africa has one of the richest subsoils in the world, it is reasonable to think that African countries should also be ones where it makes for a good life. But the opposite is true. Take the cases of the Democratic Republic of Congo, South Sudan, Central African Republic and Nigeria, for example.

Several African Roman Catholic bishops lamented this during the last Synod on Africa in 2009. Bishop Edward Tamba Charles, archbishop of Freetown and Bo in Sierra Leone, deplored that the African populations living on oil deposits or minerals were also the poorest. ${ }^{14}$ Other peers have denounced how savage and irresponsible exploitation of natural resources and the environment by rapacious and unscrupulous international businessmen and corporations "has a negative impact on Africans and threatens their prospects for living in peace". ${ }^{15}$ Bishop Lucius Iwejuru Ugorji, bishop of Umuahia, Nigeria, said that "environmental degradation in Africa is linked to this problem" and that "whole countries are

10 Sourou JB. 2017. “10 January: Political calculation or response to a socio-anthropological requirement in Benin?", in Green MC, Hackett RIJ, Hansen L and Venter F (eds). Religious pluralism, heritage and social development in Africa. Stellenbosch: AFRICAN SUN MeDIA.

11 Sourou, Rivogliono il loro pesce, 118-122.

12 Barma AB. 2017. "Bénin/FMI: à Cotonou, le jeu d'équilibriste de Christine Lagarde", La Tribune Afrique, 12 November.

13 Myrie C. 2015. “Why do people want to leave Eritrea?” BBC, 10 November; Runde DF. 2018. "What Peace in Eritrea Means for Forced Migration", Center for Strategic and International Studies, 12 July.

14 Sourou JB. 2010. L'ora della maturità [The time of maturity]. Bologna: EMI, 21.

15 Sourou, L'ora della maturità, 21. 
being destroyed by deforestation, oil spills, product dumps toxic, plastic containers or cellophane. Erosion of human origin sweeps over arable land, devastates roads and silts water sources." ${ }^{16}$ As the Bishop noted, "These factors further impoverish African communities and increase tensions and conflicts." 17 These populations then become potential candidates for emigration, easy prey in the hands of the many sellers of smoke and touts who ply Africa, plucking from the vulnerable the few goods they have left.

Several investigations have shown how the exploitation of oil in the Niger Delta by foreign oil companies especially Western does not respect the environment and thus the life and the living environment of the indigenous populations, thus forcing them to an infernal life made of pollution atmospheric (gas flaring), acoustics (incessant noise of innumerable oil drilling rigs), degradation of fauna and flora (pollution of rivers, acidity of rain and arable land, massive death of game and fish). ${ }^{18}$ This forces people to abandon their villages to find better places to live. Moreover, the lack of work and the non-employment of young people by oil companies, who extract and export oil without employing local workers, is an important factor of economic and social destabilisation. This leads many times to rebellions and all kinds of violence in the Delta area.

To these environmental problems on the continent can be added the numerous wars linked to the exploitation of the raw materials which abound in Africa. ${ }^{19}$ The case of the Democratic Republic of Congo is strongly emblematic. "The natural resources of the DRC fuel the lust of certain powers and are not unrelated to the violence that is imposed on its people ... all conflicts are taking place in the economic corridors and around the mining wells", said bishop Nicolas Ndjomo Lola, the bishop of Tshumbé and president of the National Episcopal Conference of the Congo (CENCO), during his speech at the 2009 Synod on Africa. He also denounced "the plans of balkanisation by the predators to create 'dwarf states' in Africa, manipulable at will by the powerful of this world who act by the multinational companies and relay persons in Africa and especially in the DRC. ${ }^{20}$ This cry of alarm from the Congolese bishops applies to many other situations of this kind.

On the other hand, the three-decade war between south and north Sudan, ${ }^{21}$ apart from the number of dead, has created a group of young people whom the United Nations has called the "lost generation". They are young people who never went to school and who were constantly in the bush to protect themselves. The current humanitarian crisis in the young Republic of South Sudan is classified at Level 3 by

\footnotetext{
16 Sourou, L'ora della maturità, 21.

17 Sourou, L'ora della maturità, 22.

18 Cf. Sourou, Rivogliono il loro pesce, 126-132.

20 Cf. Sourou, Rivogliono il loro pesce, 20-21.

21 Cf. Sourou, Rivogliono il loro pesce, 147-151.
} 
the United Nations, the same as that of the crisis in Syria. ${ }^{22}$ More than 2.5 million people were displaced, 4 million people (half of the population) are starving and nearly 50,000 children are suffering from acute malnutrition in a land rich in oil, which has been one of the main causes of the war in this country, the youngest state of the world, which has been independent only since 2011.

On the same side, the intentional and organised fall of Colonel Muammar Gaddafi in 2011, in addition to creating chaos in the country, facilitated the circulation of weapons of all kinds in the Sahel regions of Niger, Mali and Chad, as well as armed incursions in northern Nigeria and Cameroon. Oil and gas leave Libya upstream, but downstream, people are massacred, terrorists circulate, attacks are increasing and the number of refugees and candidates for emigration is increasing. ${ }^{23}$ Those who used to go to Libya for economic reasons, following the existent traditional migration roads ${ }^{24}$ face violence by armed groups who profit from them find themselves disoriented, and this may in the long run destabilise many other countries, whose citizens find themselves without a source of employment and income. The well-being of the African people is compromised by these factors, but it is also not possible without local complicity in various ways and to different degrees - hence the responsibility of our own leaders.

\section{CONCLUSION}

Migratory flows: a reflection of a crisis of human flourishing in Africa? That was the opening question. And I think from the journey to this point, we can conclude that as long as Africa will not be a peaceful place for its own sons and daughters or a place where it is possible to have a good life for many Africans - unfortunately, the young, that is to say, the "strong arms", will look to leave. It is true that not all of them are heading West as is commonly believed, and that some Western media and populist politicians in Europe have fanned the flames of hatred, xenophobia and violence. ${ }^{25}$ Thus, Europe is not the answer to the legitimate dreams of young Africans.

Unfortunately, African history has seemed to repeat itself in recent years: sea, boats, death of African "strong arms", unknown destinations. Is it possible to reverse the trend? Yes. But only with a serious commitment, because the outcry raised by the African states following the report by the American channel CNN of African migrants sold as slaves in Libya should not divert us from one thing: the murderous silence of Africa, especially the authorities, in the face of the unnecessary death of thousands of African migrants. Because the suffering of the migrants in Libya does

22 "L'ONU relève à son maximum le niveau d'urgence humanitaire en Iraq" [UN maximises humanitarian emergency in Iraq], UN News, 14 August 2014.

23 Sourou, Rivogliono il loro pesce, 153-158.

24 Mounkaila, Africa, Europe and the Mediterranean Migration Crisis.

25 Sourou, Rivogliono il loro pesce, 15-25. The majority of migrants remain on their continent nearly nine in ten African migrants settle on the African continent, while eight out of ten Asian migrants remain in Asia. 
not date from yesterday. It is since the beginning of this exodus in the 2000s that those who landed on the Italian coasts denounced their treatment not only in Libya, but also in Morocco, for example. ${ }^{26}$

Human and total development of the Africa is possible under certain conditions, which include not only the establishment of democratic regimes, but democracies with economic and social benefits for all and not only for certain classes or persons. It means more commitment in drinking water, food security, and the sectors of health and education, particularly training that meets the expectations of the African labour market and not the West. The blossoming of the African can also not be realised if the states do not require more respect for the environment and the vitality of the population from those who exploit and mine the raw materials and are not more firm in blocking the causes of wars and other violence fomented from abroad. The same goes for the economic benefits of mining and other foreign exchange, when they are diverted for purposes other than the good of all. The path to the development of the African seems difficult, but without a minimum of effort on many levels, young people will continue to flee this beautiful and wonderful continent.

26 Cf. Sourou JB. 2016. Chronique d'un été glacial, le rêve naufragé des Africains [Chronicle of an icy summer, the wrecked dream of Africans]. Allada: CEDRES, 63-81. 